\title{
Investing in Girl Child Education for National Development
}

\author{
Illo, Charles 0.
}

Lawal, R.O.

Ezekiel, A.I.D.

School of Educatıon, Mocped, Noforija Epe, Lagos State

Mr. Loko, S.T.

Director, Time-Education Consults

\section{Doi:10.5901/mjss.2014.v5n27p692}

\section{Abstract}

Education is a key factor for the development of any nation. Education performs a major role in equipping the individual with the skill and knowledge, which will help to transform any society. It is pertinent to say that education is the greatest investment that any nation can provide for the quick development of its natural and human resources. It is against this back drop that this paper canvasses for investment in girl-child education for national development. The paper defines the concept of the girl-child; discusses girl-child education and national development; benefits of investment in girl child education; factors militating against investment in girl-child education and in conclusion recommendation are made on how to enhance the lot of the girl-child.

\section{Introduction}

Education is important for everyone, but it is especially significant for girls and women. This is true, not only because education is an entry point to other opportunities, but also because the educational achievements of women can have ripple effects within the family and across generations. Investing in girls' education is one of the most effective ways to reduce poverty. Investments in secondary school education for girls yield especially high dividends.

Akinola (2013) asserts that the girl-child right to education is an economic, social and cultural right, as well as a civil and political right since people cannot fully realize their freedom without education. Like all human rights, the context of girls' right to education can be found in our local legislation and international commitments. Despite all this, the girl child still bears the double jeopardy she suffers first as a child, then the discrimination that comes as a result of being a girl child.

It is rather unfortunate that even in the $21^{\text {st }}$ century, the female Nigerian child, especially in the Northern part of Nigeria, is denied equal access to education and most of them are exposed to harmful traditional practices like genital mutilation, denial of education, child trafficking etc. education for the girl child just as any other child is generally considered to be one of the core rights, as the basis for achieving other rights.

Statistical monitoring of education revealed that the national literacy rate for female is only $56 \%$ as compared to $72 \%$ for male. While in other states the female literacy, enrolment and achievement rates are much more and unreasonably lower to their male counterparts.

In spite of various programmes put in place by the government to promote girl-child education, it is disheartening to note that disparity in access to education is still in favour of the male children (Gidado in Umar \&Gbana, 2004).

Action Aid International (AAIN) in Akinola (2013) discovered in a research that there was gap in favour of boys in school enrolment, retention and completion. The study on girls' education revealed factors affecting girls' education as cost of education, school enrolment, government policies and their implementation, the culture of the people, among others.

\section{The Girl-Child}

The girl-child is a biological female offspring from birth to eighteen (18) years of age. According to Gistarea (2013), it is 
the age before one becomes young adult. This period covers the crèche, nursery or early childhood (0-5 years) and primary (6-12).

During this period, the young child is totally under the care of the adult who may be her parents or guardians and older siblings. It is made up of infancy, childhood, early and adolescent stages of development. During this period, the girl child is malleable, builds and develops her personality and characters.

Also, Olomukoro\&Omiunu, (2011), described girls as young adolescent females, biological being whose role in life is limited by their natural biological characteristics.

She is very dependent on the significant others, those on whom she module her behaviour through observation, repetition and imitation. Her physical, mental, social, spiritual and emotional developments start and progress to get to the peace and the young adult stage. The girl-child simply refers to the female child that has not reached the age of adult.

In this paper, the girl child is regarded as a female between the ages of 0-22 years.

\section{Girl-Child Education and National Development}

Girl-child education is a process of educating female in order to make them efficient and effective members of the society at home in their daily life duties and responsibilities. Egbo\&Mama (2011) Education enables the girl child later in life to be a useful and functional members of the society.

Development implies that the material welfare of the people has been improved upon, that poverty has been abrogated, unemployment has been greatly attenuated and that life expectancy has been considerably prolonged.

According to Mogbo in Egbo\& Mama (2011), development is purely an economic term; it means more output of goods and services in nation. That is new ideas that are hatched, new changes that are introduced, that may lead to the production of higher capital income. Development is associated with eradication of diseases, poverty, ignorance, illiteracy, unemployment and low life expectancy in any nation. Schooling was conceived as one of the necessary preconditions of National Development (Saleha 2008).

The most significant resources for national development are the human labour force/manpower.

According to Khalid in Egbo\& Mama (2011) a productive labour force equipped with effective leadership and intelligent management skills is a requirement for successful development. The manpower for development in any nation comes from the present population of children (male and female).

There is therefore a need for countries to plan for health, education, the skill training and the socio-cultural attitudes required for the development of the young generation.

\section{The Benefits of Investing in Girl-Child Education}

According to NPE (2004) education is the greatest force that can be used to bring about redress; it is the greatest investment that the nation can make for the quick development of its economics, political and human resources.

Education is fundamentally an agent of socialization of people into the socio-cultural aspect of the society. In the modern times people are becoming aware of the need and value of education, for personal, socio-economic and cultural development of the country. Today, education has been realized to be a strong weapon or agent of social integration in society.

There is an adage that says "educate a man, you educate an individual, but educate a woman, you educate a nation". This adage summarizes the essence of education of the girl-child and indeed by every educable human being. This then calls for special attention to be focused on education of the girl-child. No nation can afford to toil with the education of her citizen, especially, the child, who will be the future leader of tomorrow, because education is the bedrock of all facets of development.

Girl-child education is one of the most important investments that could be used for the future of any country. It could make an enormous difference to a woman's chances of gaining well-paid work, raising a healthy family, preventing the spread of diseases such as HIV and AIDS etc. (UNICEF, 2004) in Isife (2013).

Tsauri (2010), Egbo\& Mama (2011), Mbene (2011) and Isife (2013) all identified the following as the benefits of investing in the education of the girl-child.

Basic education provides girls and women with an understanding of basic health, nutrition and family planning, giving those choices and the power to decide over their own lives and bodies. Women's education leads directly to better reproductive health, improved family health, economic growth, for the family and for society, as well as lower rates of child mortality and malnutrition. It is also in the fight against the spread of HIV and AIDS.

Educating girls and women is an important step in overcoming poverty. The focus on poverty reduction makes the 
right to education to be a powerful tool in making a change in the lives of girls and women. Poverty has been universally affirmed as a key obstacle to the enjoyment of human rights, and it has a visible gender profile. The main reason for this is the fact that poverty results from violations of human rights, including right to education, which disproportionately affect girls and women, trapping them in a vicious downward circle of denied rights that in turn leads to exclusion from the labour market and marginalization into the informal sector or unpaid work. This perpetuates and increases women's poverty.

Investment in education benefits the individual, society and the world as a whole. Broad based education of good quality is among the most powerful instrument known to reduce poverty and inequality. Women who are care givers at home when educated will, no doubt, improve the health of their family members, and this will strengthen the nation's health and lays the foundation for sustained economic growth.

Through education, women come to know their rights and will be able to contribute their quota to the development of the society. Salawu (1989) in Tsauri (2010) posits that:

The cultural mores and folkways of a society are transmitted more effectively through its women than its men. It is the mother who gives children their training in correct social attitude, conscience, morals and manners, since they spend their formative years together before they are of conventional school age.

Educating women will provide them with the ability to fit into the modern ever changing world. To effectively fit and function optimally in today's technological world, women need to be literate.

Girls who complete primary and secondary education tend to marry later, have smaller families and earn significantly higher wages. According to Mbene (2011), girls' education has been posited as a vaccine against HIVIAIDS; analyses in Zambia of non-educated and educated women show a substantial difference in infection rates. Educating a girl changes her destiny, as well as those of her future children and ensures that she can contribute to the economic life of her community.

Higher rates of high school and university education among women, particularly in developing countries, have helped them make inroads to professional careers and better-paying salaries and wages. It can increase the level of resources available to women who divorce or are in a situation of domestic violence. It has been shown to increase women's communication with their partners and their employers and to improve rates of civic participation such as voting or holding of office.

Educational attainment correlates to increased agricultural productivity. It is reported that "increased education for women would yield exceptional returns in terms of world food security. A World Bank study, according to Mbene (2011), concluded that if women received the same amount of education as men, farm yields would rise by between 7 and $22 \%$. Increasing women's primary schooling alone could increase agricultural output by $24 \%$. Mbene (2011)

Education for women could also be highly effective in reducing the incidence of trafficking girls to borders or other countries; increasing overall environmental awareness; and reducing the likelihood of terrorism.

Unfortunately, however, there are still 24.4 million girls out of school in sub-Saharan Africa. Given the high percentage of girls excluded from education, there is definitely a case for increasing and facilitating access to education for girls as an antidote against the current situation (Mbene, 2011).

\section{Factors Militating Againstlnvestment in Girl-Child Education in Nigeria}

In Nigeria, the educational participation of girls is notably to lower than that of boys. Gender has continued to play major role in determining school attendance, performance and progress. Being a female is negatively associated with enrolment, attainment and performance (Murzi, 2003) in Olomukoro and Omiunu (2011).

Despite the fact that the Nigeria constitution (1999) guarantees the equality of all its citizen, regardless of religion, ethnic origin, circumstances of birth and above all sex, various socio-cultural and religious practices such as preference for male child, early marriage and "purdah" have gone a long way to prevent the Nigerian girl-child from exercising their legal rights to equal education to the fullest (Nwosu, 1999).

Tsauri (2010); Isife (2013); Olomukoro and Omiunu (2011); Joshua (2010); Umar \&Gbana (2004) identified various factors militating against the education of the girl-child in Nigeria, which include cultural inhibition, erroneous interpretation of religious injunctions, traditional practices, early betrothal of girls in marriage, gender insensitive educational environments, curricula and teaching methods, lack of encouragement from the wider society, poor quality of school, societal preference for the male-child and over burdening of the girl-child with household chores and labour.

The betrothal of girls for marriage at an early age is identified as a major factor that hinders the girl-child school 
enrolment, attendance and retention in Nigeria. Early betrothal is also closely tied with teenage pregnancy. Osokoya (2005) cited in Olomukoro and Omiunu (2011) reported that about 30\% of Nigerian teenagers drop out of school having already begun child bearing before the age of 18 . The emerging data on the incidence of teenage pregnancy indicates a higher rate in the North East and North West zones of 40\%, 41\% and 9\% in the South East and South West zones respectively (UNESCO, 2005), cited in Olomukoro and Omiunu (2011).

Oganwu (1996) cited in Umar and Gbana (2004) states that in Nigeria, women are expected to play the second fiddle, and to take up low status jobs. They traditionally have been debased and dishounoured by the fact that they are supposed to consider motherhood as the principal purpose of their existence. He states:

She is ...... brain washed by a culture of superior male dominance and is left to do with a life career in peasant farming or pretty trading. Her picture elicits some empathy, haggard - looking, ill, old and almost balding hair that has dutifully responded to pressures from heavily laden baskets of farm product. (Oganwu, 1996).

Hara Lambo (1980) further referred to by Oganwu (1996) in Umar and Gbana (2004) are saying that the inferior status of the female can be traced to the Holy Bible. According to him, she was the cause of original sin in the Garden of Eden and has been paying for it ever since. The book of Genesis says, "I will greatly multiply thy sorrow and thy conception. In sorrow shall thou bring forth children and thy desire shall be to thy husband and he shall rule over thee".

The discrimination against women is so strong that certain necessities are denied them.

Formal education is very essential in moulding an individual, in making one apprehensive of what is going on around him and thus making one capable of coping with problem around him. In many families education of the girls is not perceived as important. Some view it as a waste because a girl grows up and get married and the money spent on her education is never fully recovered from her bride price. In other words, education is viewed as an investment from which material and momentary gains must be realized and the best way to ensure the success of investments is to train only the male child, who later through his earnings builds a house in his father's compound, sends money home and trains other male children. A woman may be prevented by her husband from carrying out the above for her parents or society may not even allow her have such ambitions. Hence, many women have the hard luck of never being exposed to formal education.

All these factors adversely affect girl-children enrolment, attendance and retention in school and also the gender gap in education is marked high in predominantly Moslem state like Sokoto and Zamfara and has limited the access of the girl-child to educational opportunies especially post-secondary education and consequently, only a very tiny proportion usually gets into these commanding heights of national life for which higher education is a pre-requisite.

With $70 \%$ of the population living below the poverty line, girls are often sent to generate income for families by selling wares, food stuffs in the market, or on the streets.

Teenage marriage, have also militated against girl attendance, retention and achievements in school. About 30\% of school age girls drop out of school having already begun childbearing at an early age. The implication of these phenomena is that many have suffered from psychological imbalances since they are mostly not matured for managing a marital home. Sicknesses and diseases such as Vesicovaginal Fistula (VVF) have also become rampant as a result of this social problem, which the girl child solely suffers.

Cultural and religious biases are yet another factors which have indeed contributed to the low level of girl child education as many Nigeria parents, especially in large families with limited resources, enrol boys in school instead of girls.

Gender bias in content and teaching and learning processes is another factor for the regulation of the girl child education as claimed by observers. Boys are given more opportunities to ask and answer questions, to use learning materials, and to lead groups. Girls are given less time on task than boys in primary and secondary schools science classes. Teachers also use corporal punishment, thus creating an intimidating classroom environment.

\section{The Way Forward}

Based on the problem highlighted above, the following suggestions will help to improve the education of the girl-child in order to enhance their well-being and also foster national development.

The solution to these problems as discussed above includes making available the needed schools for the education of the girl child. Hence, the government must make free and compulsory education available to school agechildren, while at the same time establishing more schools to meet the rising demand for quality education.

There should be flexibility in our educational policies that will enable efficient and progressive changes to respond 
to girl-child educational needs in spite of their cultural setting. This will make room for government to recognize and provide education to children with disabilities and children deprived of their right to education.

State government must devote more time to ensure free basic education and at higher level, affordable fees. None should be discriminated against, as prevailing situation reveals, so that all existing gaps may be bridged.

The need for proper orientation of Nigerians, especially parents, community leaders, opinion leaders and religious leaders must be addressed. This will help a long way in improving the enrolment of the girl child.

Government should enforce laws that prohibit hawking and street trading by girls with penalties stipulated for violators.

Women Commission Organization and other Non-Governmental Organizations (NGOs) should co-operate with the government to facilitate and provide opportunities for formal and informal education for women folk.

The government should provide girl-child with friendly infrastructure that will motivate them to go to school.

Government should enact a policy and a legislature that will ensure that girls complete their schooling even if they get married before completing their elementary education.

The quality and quantity of teachers should be increased, taking into consideration the gender differences.

\section{The Kastina State Experiment}

The governor of Kastina state, His Excellency, Governor ShehuShema, established the Department of Girl-Child Education and Child Development in 2008, a project considered as the first of its kind in Nigeria to improve the lot and the quality of life of girls, especially those from poor background in the rural communities.

According to Audu (2013) the State Government also established schools exclusively for girls in each of the 34 Local Government Areas of the state. The department mapped out strategies and domesticated international practices such as the Female Teacher-Trainee Scholarship Scheme (FTTSS) to produce female NCE Female Teachers and Conditional Cash Transfer (CCT), among others, to improve the lot of girls from poor families in rural communities.

\section{How the Two Programmes Aid the Education of the Girl-Child}

Female Teacher-Trainee Scholarship Scheme (FTTSS) is one of the components of UNICEF/ Department for International Development (DFID), Girls' Education Project (GEP). The scheme is a special intervention providing financial support to the tune of N50,000 for each female NCE student annually for registration, education materials and general upkeep. Beneficiaries are drawn from poor families in rural communities so that at the end of their training, they are bonded to return to their communities to teach. This has helped to increase the number of qualified female teachers in rural schools. Also, it provides mentoring services to girls, makes rural schools girl-child friendly, increases enrolment, improves attendance as well as raises completion and transition rates.

FTTSS implementation in Kastina state started after 150 girls in 2008 secured admission into the State College of Education for their NCE Programme. It was agreed that the state government was to support 100 students and the remaining 50 by UNICEF/DFID. In 2009, the number of the beneficiaries increased to 240 and in 2010, it went up to 340 and after it was decided that each local government in the state should contribute 10 beneficiaries to the scheme while the state government support 80 percent and UNICEF/DFID support 20 percent.

Under the CCT scheme, the girl-child gets paid to remain in school. This is an innovation to keep the girl-child in school in a society where parent oftentimes are not disposed to educating the female children. The state government is the main financier of the CCT, with technical and moral support from UNICEF, MDGs, World Bank and other stakeholders. It is designed to increase the level of enrolment of girls in school and their retention until graduation, as well as reduce the poverty level of benefiting families. The programme is run in nine (9) LGAs. 125 primary schools are involved while 9095 female girl beneficiaries receive N5,000 each every three months. Each girl is paid the sum through her mother if she scores $80 \%$ attendance in school in the three months monitored and evaluated. (Andu, 2013).

\section{How is the Project Sustained?}

The state government has committed more than N300 million from the inception of the programme in 2009 rate to the СCT. The amount represents the expenditure incurred in establishing training, cash disbursements to beneficiaries and other logistics.

The CCT Programme Implementation Unit has disbursed five cash transfers and 12 rounds of mandatory monitoring to be followed by three rounds of monitoring preparatory to the sixth cash transfer in August, 2013. 
In appreciation of Kastina state government's commitment to the success and continuity of the programme, the Millennium Development Goals (MDG's) headquarters in Abuja contributed N200 million to facilitate successful implementation. UNICEF also engaged a resident consultant from Ayala Consulting Equador, who helped in laying solid foundation for effective and successful implementation of the CCT programme. UNICEF contributes in the areas of training and other consultative services. The need to win the CCT demands that we provide them with skills and resettlement packages. If more other states can do the same in their respective domain, the future of the girl-child would be guaranteed.

\section{Conclusion}

Education is the right of every girl-child everywhere and key to transforming her life and the life of her community. Without education, girls are denied the opportunity to develop their full potentials and to play a productive and equal role in their families, their societies, their countries and their world. Hence, the clarion calls to investing in the education of the girlchild.

\section{References}

Akinola, T. (2012) "The Girl-Child and Education Nigeria". Leadership Newspaper Group.

Audu, A. (2013) "New Woman" The Nation

Egbo, J.J \& Mama, L.E (2011) "Promoting Female Education for National Development". Journal of Women in Colleges of Education (ESCET-JOWICE) Maiden Edition pp. 109-114

Federal Republic of Nigeria (2004) National Policy on Education (Revised) Abuja. Federal Ministry of Education

Gistarea (2013) Girl Child Education - Challenges Faced in the Society. Retrieved Thursday 5, 2013

Isife C.T (2013) "The Impact of Women Education and Empowerment on National Development". Journal of Qualitative Education, Vol. 9 No. 1, pp. 90-95

Joshua, S (2010) "Nigerian Women Education in a Global Perspective". Bakatsina Journal of Education. Vol. 2 No. 1, pp. 100-103

Mbene, J (2011) "The Importance of Educating a Girl-Child". Retrieved Thursday 5, 2013

Nwosu, O (1999) the African Women: Nigeria Perspective. Lagos: Bima Publications

Olomukoro C.O \&Omiunu S.E (2011) Strategies for Expanding Access to Education to the Girl-Child in Nigeria. Journal of Adult Education and Development. Vol. 5 No 1, pp. 211-221

Saleha, P (2008) Education as Transformation of Economic and Social Structure. Bulletin of Education and Research. B Vol. 30 No. 1, pp. 33-41

Salawu, A.A (1989) "Women's Education in Islam: The Northern Nigeria Experience" Sokoto Educational Review Vol. 2 No. 1, pp. 30-41

Tsauri A.D (2010) Women Education in Kastina State: Issues, Problems and Prospects. Bakatsina Journal of Qualitative Education, Vol. 2 No. 1, pp. 78-85

Umar, M.H \&Gbana, N.S.H (2004) "Girl's Education: - An Investment for the Future". Journal of Women in Colleges of Education. Vol. 8 pp. $128-135$ 